Çukurova Üniversitesi Mühendislik Mimarlık Fakültesi Dergisi, 33(4), ss. 147-154, Aralık 2018

\title{
Küspe (Nigella sativa) Kullanılarak Sulu Çözeltilerden Adsorpsiyon ile Boyar Madde Giderimi
}

\author{
Halis SEÇME ${ }^{1}$, Serpil SAVCI ${ }^{* 1}$ \\ ${ }^{1}$ Bozok University, Engineering and Arthitecture Faculty, Biosystems Engineering Department, Yozgat
}

Geliş tarihi: $14.05 .2018 \quad$ Kabul tarihi: 25.12 .2018

Öz

Dünya'da su kirliliği en önemli problemlerden birisidir. Bu amaçla atık suların çevreye deşarj edilmeden önce arıtılması gerekmektedir. Adsorpsiyonun sulu ortamda kirleticilerin arıtımı için iyi bir proses olduğu bilinmektedir. Bu çalışmada sulu çözeltilerden Malachite green'in (MG) küspe ile (Nigella sativa) giderimi araştırılmıștır. MG'nin adsorpsiyonu üzerine $\mathrm{pH}$, başlangıç boya konsantrasyonu ve zamanın etkisi kesikli bir sistemde çalışılmıştır. Elde edilen veriler Langmuir ve Freundlich İzoterm Modellerine uygulanmıştır. Langmuir izoterm modelinin $\left(\mathrm{R}^{2}=0,9996\right)$ küspe (Nigella sativa) kullanılarak MG'nin adsorpsiyonla gideriminde en iyi uyum sağladığı görülmüştür. Ayrıca adsorpsiyon kinetiği de hesaplanmıştır. Küspe yüzey alanı ile boya arasındaki etkileşim Taramalı elektron mikroskobu ile belirlenmiştir. Çalışma, Nigella sativa küspesinin MG’nin gideriminde maliyetsiz ve güçlü bir adsorban olduğunu vurgulamıştır.

Anahtar Kelimeler: Atıksu, Küspe, İzoterm, Kinetik, Adsorpsiyon

\section{Dye Removal by Adsorption from Aqueous Solution Using Pulp (Nigella sativa)}

\begin{abstract}
In the world, water pollution is one of the most important problems. For this purpose, it is necessary that waste water must be treatment before discharge to the environment. It is known that adsorption is the well process for treatment of pollutant in an aqueous environment. In this study, the removal of Malachite green (MG) from aqueous solution using pulp (Nigella sativa) was investigated. Effects of pH, initial dye concentration and time on adsorption of MG were studied in a batch system. The available data were applied to Langmuir and Freundlich isotherms. The Langmuir model is the best fitted $\left(\mathrm{R}^{2}=0.999\right)$ for the adsorption of MG from using pulp (Nigella sativa). Moreover, kinetic of adsorption were also calculated. The interaction between the pulp surface area and the dye was determined by scanning electron microscopy. The study emphasized that the Nigella sativa pulp is a no-cost and powerful adsorbent for the removal of MG.
\end{abstract}

Keywords: Wastewater, Pulp, Isotherm, Kinetic, Adsorption

*Sorumlu yazar (Corresponding author): Serpil SAVCI, serpil.savci@bozok.edu.tr 


\section{INTRODUCTION}

Textile, food coloring, dying, printing, cosmetics and paper making industries produce hazardous materials as wastes to aqueous environment. This colored wastewater from these industries includes different kind of dyes. Otherwise, they can cause cancer, skin irrigation and allergic dermatitis. For these reason, many treatments methods such as adsorption, ion exchange, biological treatments, electrolysis and coagulation have been developed. Among of these methods, adsorption is effective methods dyes, pigments and toxic pollution. Activated carbon is high cost material as an adsorbent for the removal of dyes. Some scientist search for ecofriendly adsorbents for adsorption of pollutants as follows: rice bran for reactive blue 4 [1]; mixed fish scales for an azo dye AB113 [2]; bentonite for methylene blue [3]; calcium hydroxide for indigo carmine dye [4]; Cicer arietinum for Congo red [5]; saw dust for tartrazine [6]; An amphoteric adsorbent straw for methylene blue, methyl orange and orange II [7]; Peganum harmala-L seeds for brilliant green [8]; alginic acid foams for methylene blue [9]; Ageratum conyzoides leaf powder for methylene blue [10].

Malachite green is a basic (cationic) dye and widely used as anti-bacterial, anti-fungal and parasitical agent in fish farming. If this dye discharged into aqueous environment at least low concentration, it may cause negatively effects [11-12].

Nigella sativa is an annual flowering plant in the family Ranunculaceae which is widely used in many countries especially Eastern Mediterranean. It grows to $20-30 \mathrm{~cm}$ tall. The plant is cultivated Southern Europe, Syria, Pakistan, India, Egypt, Saudi Arabia and Iran in the world and Burdur, Afyon, Isparta, Amasya, Mersin, Istanbul, Gaziantep and Kahramanmaras in Turkey. In recent years, oil of Nigella sativa has been fixed antibacterial, antitumor, sedative, sedative, pain reliever and blood sugar-lowering [13]. Pulp of Nigella sativa are wastes from these plants industries. These wastes do not have any economic values. Also, there are no study about use of pulp of Nigella sativa in the literature, so far for MG.

In this research, Nigella sativa pulp used as an no cost and ecofriendly adsorbent for the removal of MG. Furthermore, effects of $\mathrm{pH}$, initial dye concentration and time. The adsorption isotherm and kinetics were detailed in this research. As a result, Nigella sativa pulp used as an effectively adsorbent for the adsorption of $\mathrm{MG}$.

\section{MATERIAL AND METHOD}

\subsection{Material}

\subsubsection{Preparation of Nigella sativa Pulp and Dye Solution}

Nigella sativa pulp was obtained from local market in Yozgat, Turkey. The pulp of Nigella sativa used after shred (Figure 1).

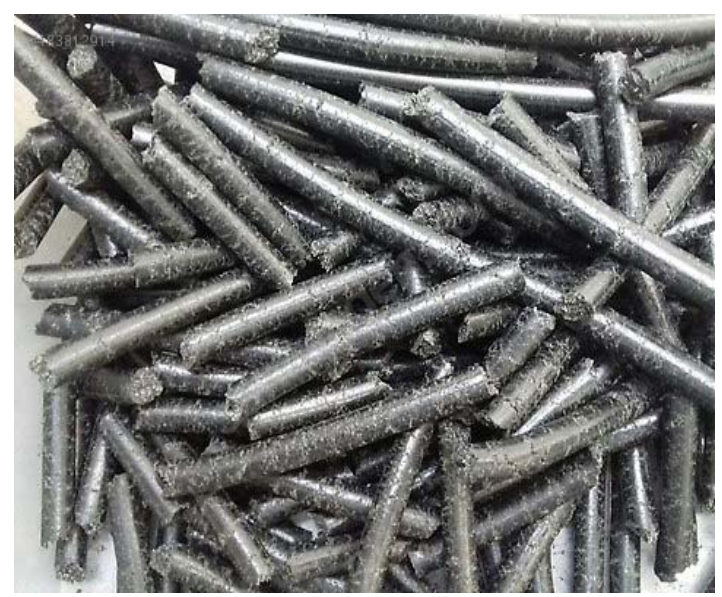

Figure 1. Nigella sativa pulp

MG was purchased from (Carlo Erba Reagent). It is a cationic dyestuff (chemical formula $\mathrm{C}_{23} \mathrm{H}_{25} \mathrm{CIN}_{2}$, dye purity $>90 \%$ ) shown in Table 1 . This dye was commercial product and used without purification. Test solutions containing MG were prepared by fresh stock dyes solution. The $\mathrm{pH}$ of the dye were adjusted solutions (0.1 N HCl-NaOH). 
Table 1. MG characteristics [14]

\begin{tabular}{|l|c|}
\hline \multicolumn{2}{|c|}{ MG } \\
\hline $\begin{array}{l}\text { Molecular weight } \\
(\mathrm{g} / \mathrm{mol})\end{array}$ & 364.90 \\
\hline Color & \multicolumn{2}{|c|}{ Green } \\
\hline$\lambda_{\max }(\mathrm{nm})$ & 619 \\
\hline Dye purity & $<90 \%$ \\
\hline Chemical formula & $\mathrm{Cl}_{23} \mathrm{H}_{25} \mathrm{CIN}_{2}$ \\
\hline & \\
\hline
\end{tabular}

Adsorption studies were performed in $100 \mathrm{~mL}$ Erlenmeyer including $0.3 \mathrm{~g}$ of pulp of Nigella sativa with $30 \mathrm{~mL}$ of $\mathrm{MG}$ solution. All the adsorption experiments were performed at room temperature $\left(25^{\circ} \mathrm{C}\right)$ via batch method. The solution was shaken by a mechanical shaker (VWR) at the constant agitation time (150 rpm) during 24 hours. Then the supernatant was centrifuged at $4000 \mathrm{rpm}$ and 10 minutes in a centrifuge (Hettich Zentrifugen) after the batch tests. The absorbance of $\mathrm{MG}$ was measured at maximum wavelength $\left(\lambda_{\max }: 619 \mathrm{~nm}\right)$ by UV-VIS Spectrophotometer (Shimadzu UV 1208 ).

For the contact time experiments, the initial dye concentrations were diverse from 100 to $2000 \mathrm{mg} / \mathrm{L}$. The incubation time was tested in a time from 10 to $180 \mathrm{~min}$. All experiments were repeated twice. The adsorption amount of MB was calculated as follows, Eq. 1:

Amount of adsorption $\mathrm{Q}=\frac{\left(C_{o}-C_{t}\right) V}{m}$

$\mathrm{C}_{\mathrm{o}}$ : The initial dye concentration $(\mathrm{mg} / \mathrm{L})$

$\mathrm{C}_{\mathrm{t}}$ : The dye concentration after adsorption,

$\mathrm{V}$ : dye volume $(\mathrm{mL}), \mathrm{m}$ adsorbent mass $(\mathrm{g})$ [15].

\section{RESULTS}

\subsection{Sem Images}

SEM photos of unloaded and dye loaded Nigella sativa pulp presented Figure 2. The Nigella sativa pulp surface filled with large amount of dyes (b).
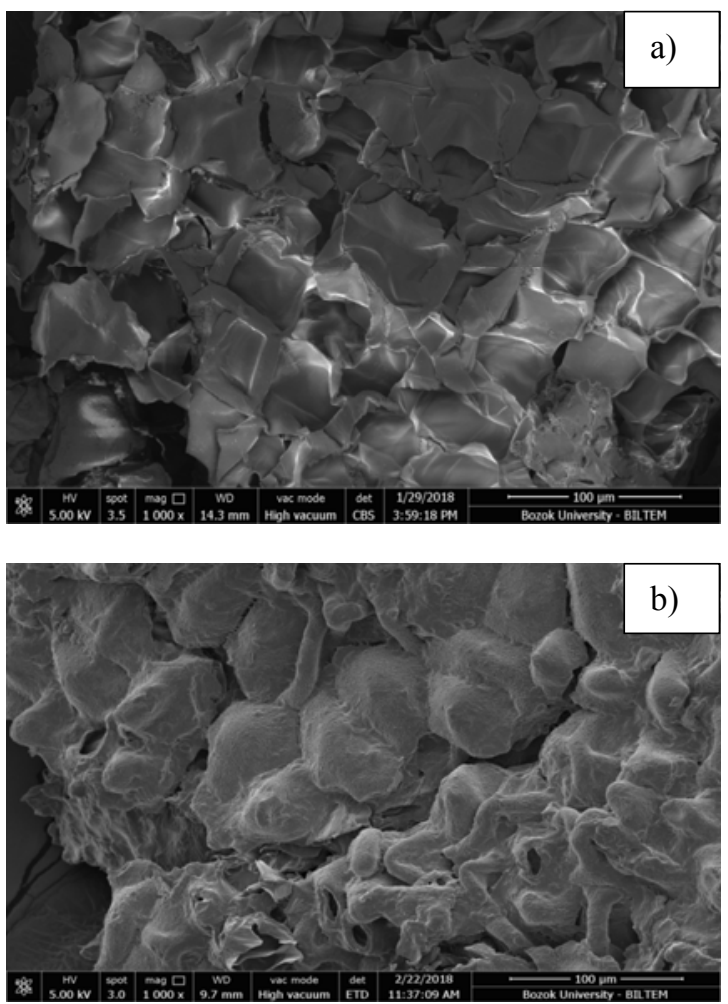

Figure 2. SEM Images of unloaded (a) and dye loaded (b) Nigella sativa pulp

\subsection{Effect of pH}

The $\mathrm{pH}$ (2.6-10) for $\mathrm{MG}(100 \mathrm{mg} / \mathrm{L})$ at room temperature. The $\mathrm{pH}$ effect results are shown in Figure 3. It is shown in Figure 3 that the adsorption of the MG increases with increasing $\mathrm{pH}$ from 2.6 to 10 . Similar results have been described for methylene blue adsorption on cotton waste, stalk and dust [16] and jackfruit pell [17]. Coşkun et al., [26] removal of methylene blue onto almond shell by adsorption. They found similar results and they explained that low adsorption capacity of almond shell due to the competitive adsorption 
between cationic dye and excess $\mathrm{H}+$ in the solution at low $\mathrm{pH}$.

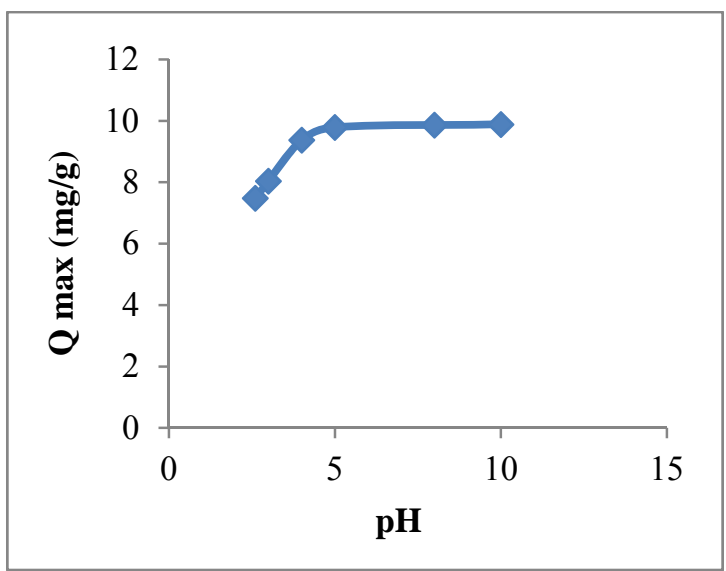

Figure 3. Effect of $\mathrm{pH}$

\subsection{Initial Dye Concentration Effect}

The initial MG concentration and time effect on the removal of MG by Nigella sativa pulp was studied at room temperature (Figure 4 and 5). As can be seen from Figure 4 with an increased in initial dye concentration from 100 to $2100 \mathrm{mg} / \mathrm{L}$ the adsorption capacity of MG by Nigella sativa increased due to increased driving force [27]. The adsorption capacity of $\mathrm{MG}$ after $1000 \mathrm{mg} / \mathrm{L}$ is stable.

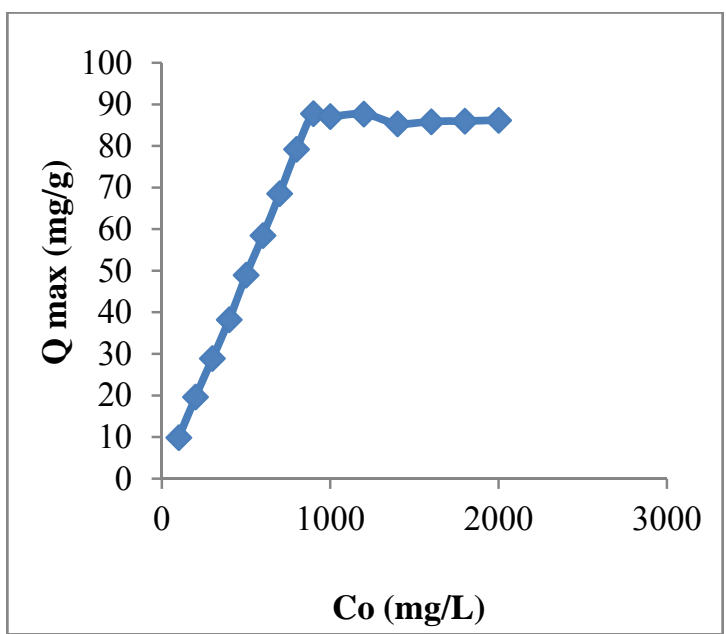

Figure 4. Initial dye concentration

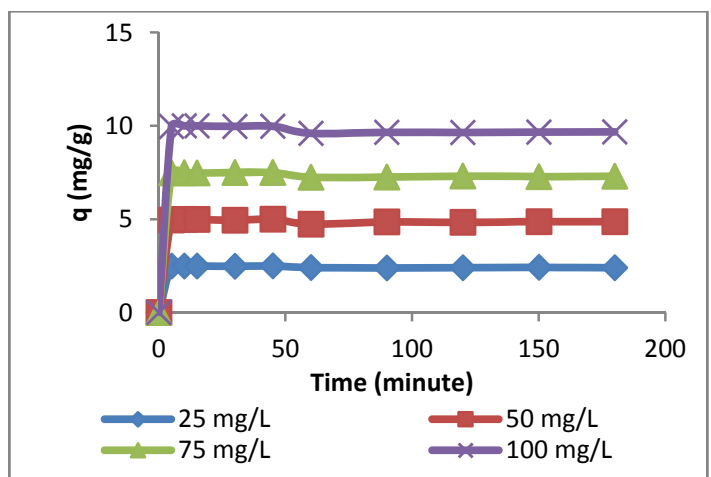

Figure 5. Effect of time

\subsection{Isotherm Study}

There are many isotherm models provide information about surface properties and adsorption mechanism. This study emphasis Langmuir $\left(\mathrm{q}_{\max }=87,309 \mathrm{mg} / \mathrm{g}\right)$ and Freundlich Models (Figure 6 and 7) at room temperature. Table 2 is presented the adsorption values of $\mathrm{MG}$ onto Nigella sativa pulp and compared other studies.

Langmuir model is given by Eq 2 [18]:

$\frac{C_{e}}{q_{e}}=\frac{1}{K_{L}}+\left(\frac{a_{L}}{K_{L}}\right) C_{e}$

$\mathrm{C}_{\mathrm{e}}$ : The equilibrium concentration of adsorbate in solution after adsorption $(\mathrm{mg} / \mathrm{L})$

$\mathrm{q}_{\mathrm{e}}$ :The equilibrium solid phase concentration (mg/g),

$\mathrm{K}_{\mathrm{L}}(\mathrm{L} / \mathrm{g}) ; \mathrm{a}_{\mathrm{L}}(\mathrm{L} / \mathrm{mg})$ : Langmuir constants.

Freundlich isotherm indicated Eq

$\log q_{e}=\log K_{F}+\frac{1}{n} \log C_{e}$

$\mathrm{K}_{\mathrm{F}}(\mathrm{L} / \mathrm{g})$ : The adsorption capacity

$1 / n:$ Intensity of adsorption

Langmuir model, describes the monolayer adsorption of dye molecules on a homogeneous 
surface. On the other hand, Freundlich model supposes a heterogeneous surface.

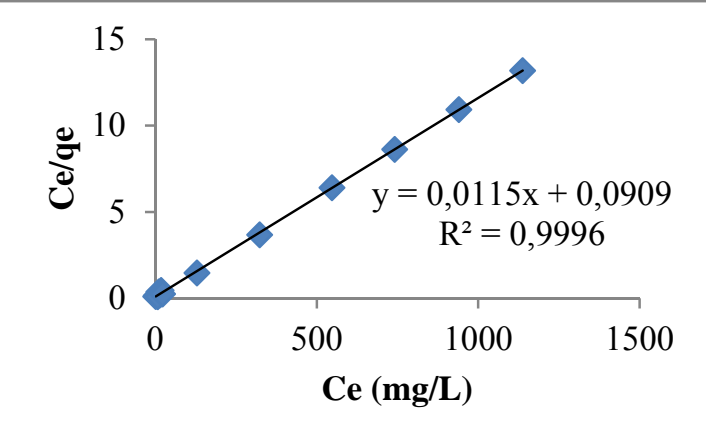

Figure 6. Langmuir isothem

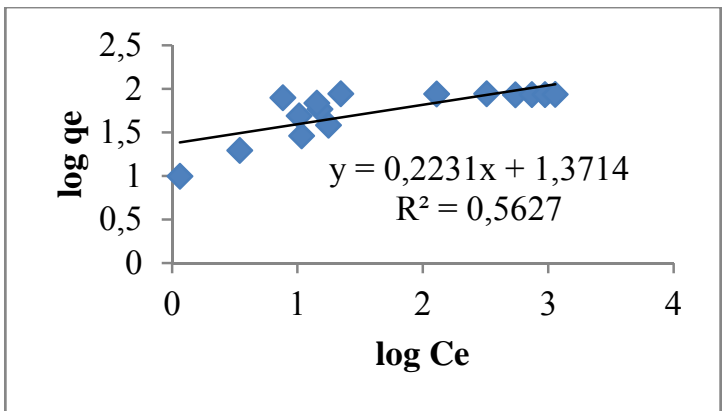

Figure 7. Freundlich isotherm

Table 2. The comparison of experimental values of Nigella sativa pulp for some cationic dyes

\begin{tabular}{|l|c|c|c|}
\hline Adsorbent & Dyes & $\begin{array}{c}\text { Capacity } \\
(\mathrm{mg} / \mathrm{g})\end{array}$ & References \\
\hline $\begin{array}{l}\text { Nigella } \\
\text { sativa pulp }\end{array}$ & $\begin{array}{c}\text { Malachite } \\
\text { green }\end{array}$ & 87,309 & This study \\
\hline perlite & $\begin{array}{c}\text { Methylene } \\
\text { blue }\end{array}$ & 0.73 & {$[19]$} \\
\hline $\begin{array}{l}\text { Grass } \\
\text { waste }\end{array}$ & $\begin{array}{c}\text { Methylene } \\
\text { blue }\end{array}$ & 80.63 & {$[20]$} \\
\hline $\begin{array}{l}\text { Pumpkin } \\
\text { sheel hull }\end{array}$ & $\begin{array}{c}\text { Methylene } \\
\text { blue }\end{array}$ & 15.33 & {$[21]$} \\
\hline $\begin{array}{l}\text { Wood } \\
\text { apple }\end{array}$ & $\begin{array}{c}\text { Malachite } \\
\text { green }\end{array}$ & 35.84 & {$[22]$} \\
\hline $\begin{array}{l}\text { Modified } \\
\text { clay }\end{array}$ & $\begin{array}{c}\text { Malachite } \\
\text { green }\end{array}$ & 40.48 & {$[23]$} \\
\hline $\begin{array}{l}\text { Arunda } \\
\text { donax root } \\
\text { carbon }\end{array}$ & $\begin{array}{c}\text { Malachite } \\
\text { green }\end{array}$ & 8.49 & {$[28]$} \\
\hline
\end{tabular}


Kinetic models are also studied for the removal of MG and pseudo second order model is the best one to compare the other models. Nigella sativa pulp can be suggest as no cost adsorbent for the adsorption of cationic dyes.

\section{REFERENCES}

1. Hong, G.H., Yi Kai Wang, Y.K., 2017. Synthesis of Low-cost Adsorbent from Rice Bran for the Removal of Reactive Dye Based on the Response Surface Methodology. Applied Surface Science, 423, 800-809.

2. Ooi, J., Lee, L.Y., Hiew, B.Y.Z., ThangalazhyGopakumar, S., Lim, S.S., Gan, S., 2017. Assessment of Fish Scales Waste as a Low Cost and Eco-friendly Adsorbent for Removal of an Azo Dye: Equilibrium, Kinetic and Thermodynamic Studies. Bioresource Technology, 245, 656-664.

3. Hamid, S.A., Shahadat, M., Ismail, S., 2017. Development of Cost Effective Bentonite Adsorbent Coating for the Removal of Organic Pollutant. Applied Clay Science, 149, 79-86.

4. Ramesh, T.N., Kirana, D.V., Ashwini, A., Manasa, T.R., 2017. Calcium Hydroxide as Low Cost Adsorbent for the; Effective Removal of Indigo Carmine Dye in Water. Journal of Saudi Chemical Society, 21, 165-171.

5. Somasekhara Reddy, M.C., Nirmala, V., 2017. Bengal Gram Seed Husk as an Adsorbent for the Removal of Dye From Aqueous SolutionsBatch Studies. Arabian Journal of Chemistry, 10, 2554-2566.

6. Banerjee, S., Chattopadhyaya, M.C., 2017. Adsorption Characteristics for the Removal of a Toxic Dye, Tartrazine from Aqueous Solutions by a Low Cost Agricultural byproduct. Arabian Journal of Chemistry, 10(2017), 1629-1638.

7. Lina, Q., Wang, K., Gaoa, M., Bai, Y., Chen, L., Ma, H., 2017. Effectively Removal of Cationic and Anionic Dyes by $\mathrm{pH}$-sensitive Amphoteric Adsorbent Derived from Agricultural Waste-wheat Straw. Journal of the Taiwan Institute of Chemical Engineers, 76, 65-72.
8. Agarwal, S., Gupta, V. K., Ghasemi, M., Azimi-Amin, J., 2017. Peganum Harmala-L Seeds Adsorbent for the Rapid Removal of Noxious Brilliant Green Dyes from Aqueous Phase. Journal of Molecular Liquids, 231, 296-305.

9. Pettignanoa, A., Tanchouxa, N., Cacciaguerra, T., Vincent, T., Bernardi, L., Guibal, E., Quignard, F., 2017. Sodium and Acidic Alginate Foams with Hierarchical Porosity: Preparation, Characterization and Efficiency as a Dye Adsorbent. Carbohydrate Polymers, 178, 78-85.

10. Ezechi, E.H., Kutty, S.R.B.M., Malakahmad, A., Isa, M.H., 2017. Characterization and Optimization of Effluent Dye Removal Using a New Low Cost Adsorbent: Equilibrium, Kinetics and Thermodynamic Study. Process Safety and Environmental Protection, 98, 16-32.

11. Intra deo mall, Srivastage, V.C., Agarwal, N., K., Mishara, I.V., 2005. Adsorptive Removal of Malachite Green Dye from Aqueous Solution by Bagasse Fly Ash and Activated Carbon Kinetic Study and Equilibrium Isotherm Analyses. Colloids and Surfaces A: Physicochemical and Engineering Aspects. 264, 17-28.

12. Kumar, K.V., Sivanesan, S., Ramamurthi, V., 2005. Adsorption of Malachite Green Onto Pithophora sp., a Fresh Water Algae: Equilibrium and Kinetic Modelling. Process Biochemistry, 40, 2865-2872.

13. Kılıç, C., Arabac1, O., 2016. Çörek Otu (Nigella sativa L.)'nda Farklı Ekim Zamanı ve Tohumluk Miktarının Verim ve Kaliteye Etkisi, Journal of Adnan Menderes University Agricultural Faculty, 13(2), 49-56.

14. https://en.wikipedia.org/wiki/Methylene_blue. Erişim Tarihi: 02.06.2015.

15. Baek, M.H., Ijagbemi, C.O., Se-Jin, O., Kim, D.S., 2010. Removal of Malachite Green from Aqueous Solution Using Degreased Coffee Bean, Journal of Hazardous Materials, 176, 820-828.

16. Ertas, M., Acemioglu, B., Alma, M.H., Usta, M., 2010. Removal of Methylene Blue from Aqueous Solution Using Cotton Stalk, Cotton 
Waste and Cotton Dust, Journal of Hazardous Materials, 183, 421-427.

17. Hameed, B.H., 2009. Removal of Cationic Dye from Aqueous Solution Using Jackfruit Peel as Nnon-conventional Low-cost adsorbent, Journal of Hazardous Material, 162(1), 344-350.

18. Abdi, J., Vossoughi, M., Mahmoodi, N.M., Alemzadeh, I., 2017. Synthesis of MetalOrganic Framework Hybrid Nanocomposites Based on GO and CNT with High Adsorption Capacity for Dye Removal. Chemical Engineering Journal 326, 1145-1158.

19. Ho, Y.S., 2006. Isotherms for the Sorption of Lead onto Peat: Comparison of Linear and Non-Linear Methods. Polish Journal of Environmental Studies, 15(1), 81-86.

20. Acemioğlu, B., 2005. Batch Kinetic Study of Sorption of Methylene Blue by Perlit, Chemical Engineering Journal, 106, 73-81.

21. Hameed, B.H., El-Khaiary, M.I., 2008. Removal of Basic Dye from Aqueous Medium Using a Novel Agricultural Waste Material: Pumpkin Seed Hull, Journal of Hazardous Material, 155, 601-609.

22. Sartape, A.S., Mandhare, A.M., Jadhav V.V., Raut, P.D., Anuse, M.A., Kolekar, S.S., 2017. Removal of Malachite Green Dye from Aqueous Solution With Adsorption Technique Using Limonia Acidissima (Wood Apple) Shell as Low Cost Adsorbent. Arabian Journal of Chemistry, 10, 3229-3238.

23. Arellano-Cárdenas, S., López-Cortez, S., Cornejo-Mazón, M., Mares-Gutiérrez, J.C., 2013. Study of Malachite Green Adsorption by Organically Modified Clay Using a Batch Method. Applied Surface Science, 280, 74-78.

24.Zhang, J., Li, Y., Zhang, C., Jing, Y., 2008. Adsorption of Malachite Green from Aqueous Solution Onto Carbon Prepared from Arundo Donax Root. Journal of Hazardous Materials, 150, 774-782.

25. Ozdes, D., Gundogdu, A., Duran, C., Senturk, H.B., 2010. Evaluation of Adsorption Characteristics of Malachite Green onto Almond Shell (Prunus dulcis), Separation Science and Technology, 45, 2076-2085.

26. Coşkun, R., Savcı, S., Delibaş, A., 2018. Adsorption Properties of Activated Almond
Shells for Methylene Blue (MB), Environmental Research \& Technology, 1(2), 31-38.

27. Bulut, Y., Aydin, H., 2006. A Kinetics and Thermodynamics Study of Methylene Blue Adsorption on Wheat Shells, Desalination, 194 (1-3), 259-267.

28. Zhang J., Li, Y., Zhang C., Jing Y., 2008. Adsorption of Malachite Green from Aqueous Solution Onto Carbon Prepared from Arunda Donax Root. Journal of Hazardous Material, 150, 774-782. 
